\title{
Role of asthma education in the management of adult asthma
}

\author{
JOHANNE CÔTÉ MD \\ Centre de pneumologie. Hôpital Laval, Sainte-Foy, Québec
}

J CôTÉ. Role of asthma education in the management of adult asthma. Can Respir J 1995;2(Suppl A):38A-42A.

When at patient is newly diagnosed as having asthma, he or she is often preseribed new medicattion without getting much information on the discatse and its reatment. This article emphasires the need to educate asthmatics. Asthma treatment should begin with a proper adjustment of the medication, allowing asthmatics to lead a nomal life. All asthmatics should be shown how to use their inhalation device properly. They should be knowledgeable about the basic aspects of asthma, airway inflammaltion and bronchoconstriction, use of medicition ind carly symptoms heralding an asthma attack. Environmental factors that may trigger an asthma attack should be explained. Patients should be able to self-monitor asthmal using either symptom severity or a peak llow meter. Becausc asthma is an unpredictable disease, pattients should have a self-action plan to implement when their asthma detcriorates.

Key Words: Action plan, Asthma commol, Edacation. Peak expiratory flow rac

\section{Le rôle de l'éducation en matière d'asthme dans la prise en charge de l'asthme de l'adulte}

RÉSUMÉ : Lorsque un patient est nouvellement diagnostiqué comme étant asthmatique, on lui prescrit souvent de nouveaux médicaments sans lui fournir beaucoup d'informations sur l'asthme et sur son traitement. Cet article met l'accent sur le besoin d'éduquer les asthmatiques. Le traitement de l'asthme devrait débuter par un ajustement adéquat de la médication pour permettre aux asthmatiques de mener une vie normale. Tous les asthmatiques devraient apprendre à utiliser leurs inhalateurs correctement. Ils devraient aussi connaître les aspects fondamentaux de l'asthme : I'inflammation des voies aériennes et la bronchoconstriction. De même, ils devraient savoir utiliser leurs médicaments et reconnaître les symptômes précurseurs d'une crise d'asthme. Les facteurs environnementaux qui peuvent déclencher une crise d'asthme devraient aussi leur être expliqués. Les patients asthmatiques devrilent pouvoir s’autosurveiller en se basanı sur la sévérité des synptômes ou la lecture d'un débitmètr de pointe. Parce yuc lasthme est imprévisible, les patients devraient avoir leur propec plan deaction en cals d’aggravation de lat malatdic.
STHMA is A COMMON DISEASE THAT AFFECTS 5 TO I0\%
Lof the population of North America. Although there has
been considerable improvement in the medications available
for its treatment over the past decade, asthma remains one of
the rare treatable diseases for which no improvement in the
mortality rate has been observed in Canadit until recently (1).
Retrospective studies on patients who died from status asthmaticus have shown that about $80 \%$ of those dearhs could have been prevented by improved knowledge of the disease by both the patient and the medical personnel (2-5). Some potentially avoidable factors have been identified: underestimation of asthma symptoms by the patient; poor compliance

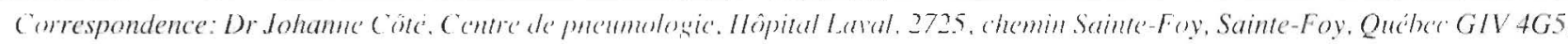
Telephone (418) 656-4747, Fax (418) 656-470)? 
with treatment; underusc of objective kests to estimate the level of airflow obstruction; and excessive delay before consulting a physician.

Mortality from asthma is only a small fraction of the problem. All Canadian statistics show an increase in morbidity associated with the condition. Indeed, the number of hospitali/ations due to asthma among pittients under 35 yeurs of age has increased significantly over the past decade (1). Recent studies in Canada and the United States have shown that this disease represents a considerible conomic burden (6). For instance, in the United States, the direct costs associated with asthma were estimated at US\$6 billion in 1989, while in Canadil, the same costs amounted to cLN\$220 million in 1990.

Improved management of asthma is a potential way 10 reduce the socioceonomic and human burden associated with this discasc (7). This articte discusses some important issue that should be considered once the diagnosis of asthma is confirmed. Asthma being an unpredictable disease, asthmatics should be provided with information and taught to develop selt-management skills to decrease both the frequency and severity of asthma flare-ups.

\section{ASTHMA EDUCATION: A SOLUTION TO THE PROBLEM}

A few randomized studies have shown that a structured educational program administered by specialized educators provides benefits to asthmatic patients in the educated groups compared with control groups (8-13). After participation in an asthma education program, asthmatics showed improved compliance with treatment compared with the placebo group, as well ats a reduction in the severity of asthma symptoms. They used their inhalers properly in $95 \%$ of cases, compared with $48 \%$ of subjects in the control group (11). Among patients sensitied to house dust mites, those taking part in the educition program were more likely to modify their enviroment in order to reduce their exposure. Among patients consulting frequently at emergency rooms, a significant reduction in the number of hospitalizations and emergency room visits were observed after participation in a structured asthma education program provided shortly after their visit to the emergency room (10). The programs that were successful at improving outcomes included a minimum of $2 \mathrm{~h}$ of individual or group teaching. The programs that were the most effective were those aimed at changing pationts behaviour and not at exchsively increasing their knowledge (11.14.15). The important issues covered by these programs are summarized below. These areas should be included in the design of asthmat management programs for adult asthmatics ( 16 ).

Physiopathology of asthma: With the usc of visual aids, brief explanations are given regarding the physiopathology of asthma, with an emphasis on the difference between bronchoconstriction and inflammation.

Drug and delivery system: The bronchodilators and antiinflammatory medications can be administered as dry pow ders with a Turbuhaler (Astra, Lund, Sweden), Rotahaler (Glaxo, London, England) or Diskhaler (Glaxo) or ats atero- solized particles from metered dose inhalers with or without a spacer. Although the technical difticulics inherent in these devices can vary from one to another and from one individual to another, all of them without exception require adequate and repeated training in the appropriate steps to deliver the right amount of medication. Studies on how patients use metered inhalers showed that more than $\$(5 \%$ did not know how to use them properly before laking part in an asthmat education program $(7,11,17)$.

Criteria of asthma control: Adequate asthma control meatns that patients are able to exercise without significant symp toms, to perform their usual activities with minimal symptoms, to have uninterrupted sleep, and to use an inhaled bronchodilator ideally less than once daily.

If peak expiratory flow rates (PEFR) are measured, they should ideally show a less than $15 \%$ diurnal fluctuation and optimal PEFR at 80 to $85 \%$ of the best value measured.

In most asthmatic patients, proper adjustment of anti-inflammatory medication and bronchodilator therapy should fulfill these criteria (18). However, in more scvere asthma. they are sometimes impossible to achieve. If so, oral steroid therapy is often required, and the objectives of treatment are to provide the best quality of life possible with minimal side effects from the medication.

Patients should be informed of the symptoms that herald an exacerbation of asthma such as the development of a cough, particularly at nighttime, progressive breathlessness while performing regular tasks, an increase in bronchodilator use to twice the usual dose and, finally, morning or nocturnal awakening from respiratory symptoms.

Triggering factors - irritants: Patients often liave little knowledge of the nonallergic triggering factors that cam induce in asthma attack. They should be told that asthma symptoms can be precipitated by exposure to irritant latetors stch als strong odours (paint, varnish, cleaning products, etc), smohe, exposure to cold air or moderate exercise, particularly in cold weather or in places where the air is hot and dry. Education should help asthmatics to avoid exposure to these irritating factors with the exception of cold atir and exercise. The use of bronchodilators. cromoglycate or nedocromil before exposure to cold air or before exercising will help prevent the bronchoconstriction induced by these factors.

Precipitating factors that increase airway inflammation: This category of factors includes both allergens and viral respiratory infections, which are responsible for $80 \%$ of emergency room visits for asthma. Unlike irritant factors that only induce a bronchoconstriction of short duration, viral infections and allergenic exposure in sensitized individuals can cause a prolonged increase in asthma symptoms and an increase in airway responsiveness lasting from a fow days to several weeks. Regarding viral infections of the upper respiratory tract, the asthmatic patient should be instructed to monitor asthma synptons closely. II symptoms increase or PEFR values decrease under a predetermined valuc, the alsthmatic patient should atjust the drug regimen according to the action plan until the symptoms and PEFR come batch to optimal values (see section on action plan). 
In individuals with a diagnosis of allergic asthma, education programs should encourage avoidance of allergens to which the patient is proven to be sensitized. Furthermore, all individuals allergic 10 anmals such as cats, dogs, rabbits, hamsters, guinea pigs and birds should be informed that prolonged contact with the animal to which the individual is sensitized will increase the risks for further worsening of asthma symptoms and bronchial hyperresponsiveness. No cat or dog specics is "nonallergenic', because allergens are mainly concentrated in the animal skin or pelt, and the only effective preventive treatment involves getting rid of the pet (19-21). Keeping the animal out of the bedroom is not useful because the antigen is easily transferred from onc room to the next. When the contact cannot be avoided for social reasons (egr family visit), the use of a prophylactic medication such as cromoglycatc or nedocromil 20 mins before the beginning of exposure can help to decrease the airway response. For asthmatics sensitized to house dust mites, measures should be taken to reduce exposure (22). Complete avoidance is impossible, but the following measures can reduce the amount of allergen present in the bedroom. The mattress and pillows should be encased in barrier material designed to repel mites. The barrier material should be wiped with a damp cloth aach time the bedding is changed. Blankets and sheets should ideally be washed weekly in hot water (at least $55^{\circ} \mathrm{C}$ ). This will both kill the mites and get rid of their excreta. Washing with cold water or dry cleaning will only destroy one of the components. Bedroom carpeting should be removed and minimized in the rest of the house.

Medication: Educators should briefly explain to the patient the role of bronchodilators and anti-inflammatory agents. Ermphasis should be put on the interval required for the anti-inflammatory to lessen asthma symptoms and on the fact that anti-inflammatory agents need to be taken on a daily busis to control respiratory symptoms when asthma is moderatc to severe. To avoid side effects (oral thrush) from inhaled steroids, patients should be instructed to rinse their mouth with water after each use. Indications and properties of the different available medications is specifically discussed elsewhere in this issuc.

Peak flow meter: The peak flow meter is a portable device that allows asthmatic patients to assess objectively the degree of airflow obstruction. Although very popular, the usefulness of this device in the long tem follow-up of asthma has to be further explored (23). The peak flow meter is especially useful in the monitoring ol pattients with moderate to severe asthma, where it helps in adjusting more precisely the minimum dose of inhaled steroids required to obtain good asthma control and in detecting asthma exacerbations at an early stage. Peak flow meters are particularly useful in the subgroup of asthmatics who poorly perceive the severity of airflow obstruction $(24,25)$. These patients usually present with minimal asthma symptoms while spirometry shows a forced expiratory volume in $1 \mathrm{~s}(\mathrm{FEV})$ that can be as low ats $50 \%$ of the predicted value. Peak flow meters can help them to diagnose asthma exacerbations sooner, preventing the development of severe airflow obstruction.
The action plan: Asthma is an unpredictable disease. Twenty-five per cent of asthma deaths occur 30 mins after the beginning of the exacerbation, and in $66 \%$ of cases, in the following $8 \mathrm{~h}$ (2). To decrease asthma morbidity and morlality, it is important that the patient be knowledgeable about the respiratory symptoms that indicate loss of asthma control as well as know what to do in such instances.

The action plan is aimed at fulfilling the following threc goals:

- to instruct the patient in recognizing the asthma symptoms that indicate the beginning of a flare-up;

- to teach the patient how to modify his or her drug regimen if asthma deteriorates;

- to teach the patient about the respiratory symptoms that indicate a severe attack of asthma and instruct him or her to go directly to the emergency room in these circumstances.

The action plan also includes a list of all the drugs repurired to maintain good asthma control. The action plan has helped the patient become involved in the treatment of the disease, enhancing self-control over the asthma and subsequently increasing self-esteem.

The action plan is set up with the participation of the patient, the physician and the asthma specialized educator once the maintenance dose of the medication required to achieve good control of asthma has been determined. Two different types of action plan can be set up: an action plan based on the monitoring of asthma symploms af an ation plan based on the monitoring of PEFR. Since patients do not always have a peak flow meter on hand, those who are given an action plan based on PEFR should also be told about the symptom-based management plan. So far, no study has confirmed the superiority of the PEFR action plan over the symptom-based action plan (26).

Most action plans include three different steps (18). The action plan recommended in the United Kingdom includes the following steps:

Zone 1: where the patient should be most of the time:

Zone 2: there is an asthma exacerbation; the treatment should be modified accordingly;

Zone 3: the danger zone; the patient should initiate treatment with oral prednisone and consult a physician without delay.

Somc action plans are based on the colour of the traffic lights - green, yellow and red - which correspond to zone 1 , 2 and 3, respectively, of the United Kingdom plan (27).

\section{ACTION PLAN BASED ON PEFR MONITORING}

Shortly after their first visit for asthma, asthmatic patients will be asked to measure PEFR morning and evening before and after bronchodilator use for two to four weeks. A followup visit should be scheduled at the end of this period. At the time of the follow-up visit, if PEFRs are within the predicted value for the patient's age, sex and height, and PEFR circarfian fluctuation is less than $15 \%$, the asthma can be considered stable and the medication should be kept at the same kevel or decreased. If it is not meeting the criteria for good asthma control, the medication should be increased and the 


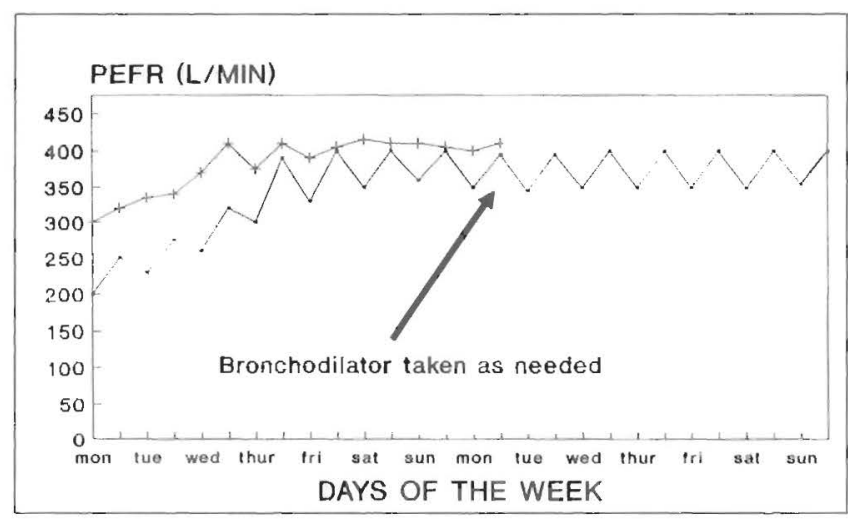

Figure 1) Peak expiratory flow rate values recorded over a twowe'k periad in a sample patient. PEFR Peak expiratory flow rats:

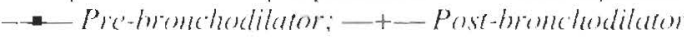

patient should continuc monitoring for two or four additional weeks. Once stabilized, the maximal value recorded by the pationt should be determined and used to set up the action plan. This maximal value of PEFR can be sometimes higher or lower than the predicted value. In severe asthmatics, it is often impossible to reach the predicted value.

Here is an example of an action plan that was designed for a patient with moderate bronchial hyperreactivity: $\mathrm{Mrs} \mathrm{X}$ is a 50-year-old patient who has had asthma with nasal polyps and acetylsalicylic acid intolerance for the past three years. She has been taking six to eight puffs of bronchodilator daily. Almost every night, she is woken up around 3 AM by shortness of breath and wheezing. She has marked dyspnea whenever she is exposed to cold air and has consequently stopped exercising.

Her medical history suggests moderate asthma because respiratory symptoms are present daily and necessitate frequent use of a bronchodilator for relicf. The asthma symptoms also occur regularly at night. There is poor control of asthma with bronchodilator abuse and marked restriction in physical activities. A peak flow meter was given to the patient. The PEFR measured in the office was $250 \mathrm{~L} / \mathrm{min}$ (predicted value $410 \mathrm{~L} / \mathrm{min}$ ). The patient was asked to start taking inhaled steroids (budesonide $200 \mu \mathrm{g}$ or beclomethasone $250 \mu \mathrm{g}$, two puffs twice daily). A follow-up visit was scheduled for two weeks later.

At the follow-up visit, the patient felt much better. She admitted to not using her bronchodilator more than once a day and had been sleeping atl night over the past 10 nights. Her PEFR values recorded during the past two weeks are shown in Figure 1. At first, there was at marked circadian PEFR variation, which decreased progressively with the regular use of inhaled steroids. After five days of treatment, the circadian PEFR variation was close $1015 \%$ and the patient no longer needed to use the bronchodilator morning and evening. Because her asthma was stable at the follow-up visit, the action plan shown in Table I was explained to Mrs X.

Some patients are not interested in measuring PEFR. In this case, an action plam balsed on symptoms can be set up as shown in Table 2.
TABLE 1

Action plan based on PEFR measurement

\begin{tabular}{|c|c|}
\hline Green zone & $\begin{array}{l}\text { PEFRs are }>80 \% \text { of your best value } \\
(>335 \mathrm{~L} / \mathrm{min}) \text { : continue same drug regimen }\end{array}$ \\
\hline Yellow zone & $\begin{array}{l}\text { PEFFs have remained between } 60 \text { and } 80 \% \text { of } \\
\text { your best value ( } 250 \text { and } 335 \mathrm{~L} / \mathrm{min} \text { ) for the } \\
\text { past } 24 \mathrm{~h} \text { : double the dose of inhaled } \\
\text { steroids for at least } 10 \text { days and until PEFRs } \\
\text { are }>335 \mathrm{~L} / \mathrm{min} \text {. If no asthma improvement } \\
\text { occurs after } 48 \mathrm{~h} \text {, advise your physician }\end{array}$ \\
\hline Red zone & $\begin{array}{l}\text { PEFRs are } 60 \% \text { of your best value }(<250 \mathrm{l} \text {. } \mathrm{min}) \text { : } \\
\text { take six tablets of prednisone } 5 \mathrm{mg} \\
\text { immediately and go to the closest } \\
\text { emergency room }\end{array}$ \\
\hline
\end{tabular}

PEFR Peak expiratory flow rate

TABLE 2

Action plan based on symptoms monitoring

\begin{tabular}{|c|c|}
\hline Green zone & $\begin{array}{l}\text { You are able to exercise or perform usual } \\
\text { activities without being short of breath: } \\
\text { continue same drug regimen }\end{array}$ \\
\hline Yellow zone & $\begin{array}{l}\text { You are short of breath when exercising or when } \\
\text { doing usual activities, you are taking your } \\
\text { bronchodilator twice as often as usual, you were } \\
\text { woken up last night by asthma: double the } \\
\text { dose of inhaled steroid for a minimum of } 10 \\
\text { days and until the above asthma symptoms } \\
\text { disappear. If no improvement occurs during } \\
\text { the next } 48 \mathrm{~h} \text {, advise your physician }\end{array}$ \\
\hline Red zone & $\begin{array}{l}\text { Asthma symptoms prevented you from sleeping } \\
\text { last night, you are short of breath when } \\
\text { speaking or your bronchodilator only relieves } \\
\text { symptoms for less than } 2 \mathrm{~h} \text { : take six tablets of } \\
\text { prednisone } 5 \mathrm{mg} \text { immediately and go } \\
\text { directly to the nearest emergency room }\end{array}$ \\
\hline
\end{tabular}

In summary, action plans are atned at enhancing the patient's skill at managing asthma flate-ups. Asthma being an unpredictable and chronic disease with sudden, sometimes lite threatening exacerbations, it is of prime importance that the patient be instructed what to do when asthma deteriorates. To decrease asthma mortality and morbidity abscntecism from work or school, number of hospitalizations or emergency room visits), the behaviour of the patient has to be changed. Action plans are aimed at fulfilling these specific needs.

To datc, the value of action plans has not been fully assessed. Prospective studies are ongoing to determine their usefulness and whether action plans based on PEFR are better than action plans based on symptom monitoring.

\section{CONCLUSION}

The treatment of asthma in adults has many similarities to the treatment of asthma in children. Treatment starts with an appropriate adjustment in the drug regimen to achieve the critcria of good asthma control, such als no restriction in physical activitics, minimal use of bronchodilator and no nocturnal asthma symptoms. The patient also needs to be taught how to use the inhalation device properly, the role of 
the medication, allergenic and nonallergenic asthma triggers and control of the environment. Patients also need to be taught about the symptoms indicating the beginning of an asthma flare-up and should be given a plan of action to implement in such circumstance.

\section{REFERENCES}

I. Wilhins $\mathbf{K}$, Mao Y. Trends in rate of atmission to hospital and death from asthma among children and young adults in Canaktat (turing the 1980s. Can Med Assoc J 1993; 148:185-00).

2. Sly RM. Mortality from asthmit. J Allergy Clin Immunol 1989:84:421-34.

3. Benatar SR. Fatal asthma. N Engl J Med 1986;3 [4:423-8.

4. British Thoracic Association. Death from asthma in two regions of England. BMJ 1982;295: 1251 -5.

5. Stableforth D. Death from asthma. Thor $1 x$ 1983;38:801 -5 .

6. Weiss K. Gergen PJ, Hodeson TA. An conomic evaluation of asthma in the Uniled States. N Engl J Med 1992;326:862-6.

7. Weiss K. Budeti PR. Asthma Care in the US: Conterence procedings. Med Carc 1993:3! (Suppl 4).

8. Hilton S. Anderson HR, Sibbald B, Freeling P. Controlked cvaluation of the effects of patient education on asthma morbidity in general practice. Lancet 1986;i:26-9.

9. Clark NM, Gotsch A, Rosenstock R. Patient, professional, and public education on behavioral aspects of asthmat: a revitav of strategies for change and needed reseilrch. J Asthmil 1993;30:241-55.

I1. Bolton MB, Tilley BC, Kuder J, Recves T. Schult, LR. The cost and effectiveness of an educition program for itdults with asthma. J Gen Intern Med 1991;6:401-7.

I I. Wilson SR, Scamagas P, German DF, et al. A controlled trial of two forms of self-management education for adults with asthma. Am J Med 1993;94:564-76.

12. Mayo PH. Richamn JM, Harris W. Results of at program to reduce admissions for adult asilmit. Amn Intern Med 1990;1 12:864-71.

13. Bailey W, Richards JM, Brooks MI, Song S, Windsor RA. A randomized trial to improve self-management practices of adult asthmit. Arch Intern Med [990): 150):1664-8.

14. Jenkinson D, Davion J, Ines S, Howtin P. Comparison of effects of a self-management booklet and audicxassette for patients with asthma. BMJ 1988:85:267-70.

15. Moldofsky H, Broder I, Davies G, Leznolf A. Videotape educational program for people with asthma. Can Med Assoc J [979;120:669-72.

16. Boutin H, Boulet LP. Comprendre et Mattriser I'Asthunc. Ste-Foy: Presses de l'Université Laval, 1993.

17. Guidry GG, Brown WD, Stogner SW, George RB. Incorrect use of metered dose inhalers by medical personnel. Chest [992;101:31-3.

18. Scheffer AL, Bousquet J, Busse W, et al. International consensus report on diagnosis and management of asthmit. Bethesda: National Institutes of Health, 1992.

19. Evans R, Summers J, Newill CA. Allergic reactions causced by exposure to animals. In: Lechtenstein LM, Fauci AS. Current Therapy in Allergy, Immunology and Rheumatology. Philadelphia: Decker Inc, 1988:5-6.

20. Charpin D, Chapin C. Bervloet D. Fel d I allergen: shin or saliva. Ann Allergy 1992:69:321-2.

21. Chapman MD, Platts-Mills TAE. Cat allergy. Ann Allergy 1992;69:273-5.

22. Platts-Mills TAE, Chapnitn MD. Dust mites; immunology, allergic disease, and enviromental control. I Allergy Clin Immunol 1987;80:755-75.

23. Clark NM, Evans D, Mclins RB. Paticnt use of PEFR monitoring. Am Rev Respir Dis 1992: 147:722-5.

24. McFadden ER, Kiser R, De Groot WJ. Acute bronchial asthma: relations between clinical and physiologic manifestations. N Engl J Med 1973;288:281.

25. Rubinfield AR, Pain MCF. Perception of atsthma. I anc't 1976;i:882-4.

26. Charlton I, Charlton G. Broomfield J. Mullee MA. Evaluation ol peak flow and symptoms only self-management plans for control of asthma in general practice. BMJ 1990:30 I: 1359-62.

27. Le'wis CE, Rachelfesky G, Lewis MA, Sota A. Kaplan M. A randomized trial of $\mathrm{ACT}$ (asthmal care training) for kids. Pediatrics 1984;74:478-86. 


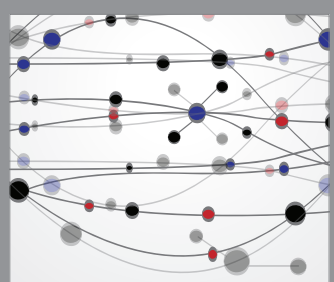

The Scientific World Journal
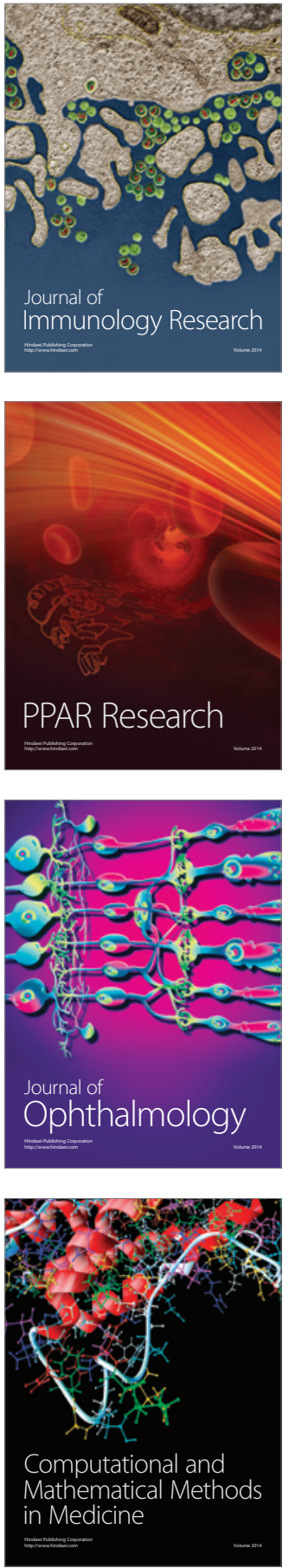

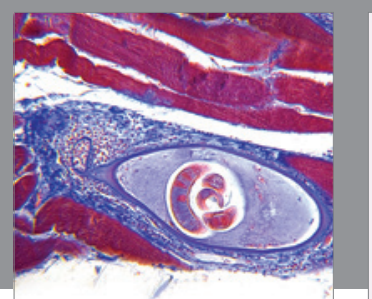

Gastroenterology Research and Practice

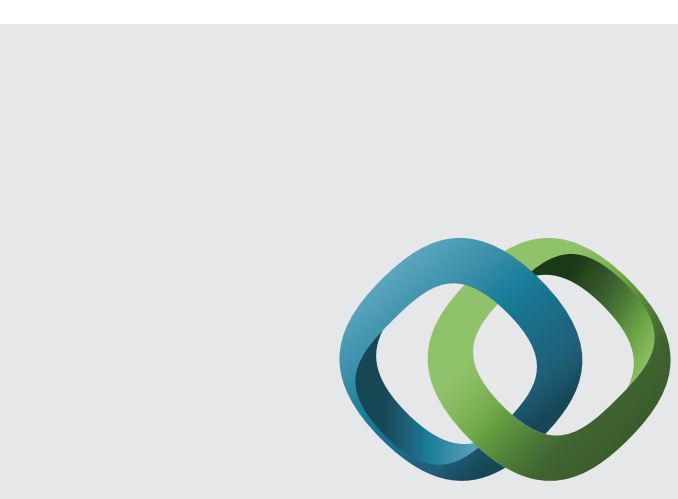

\section{Hindawi}

Submit your manuscripts at

http://www.hindawi.com
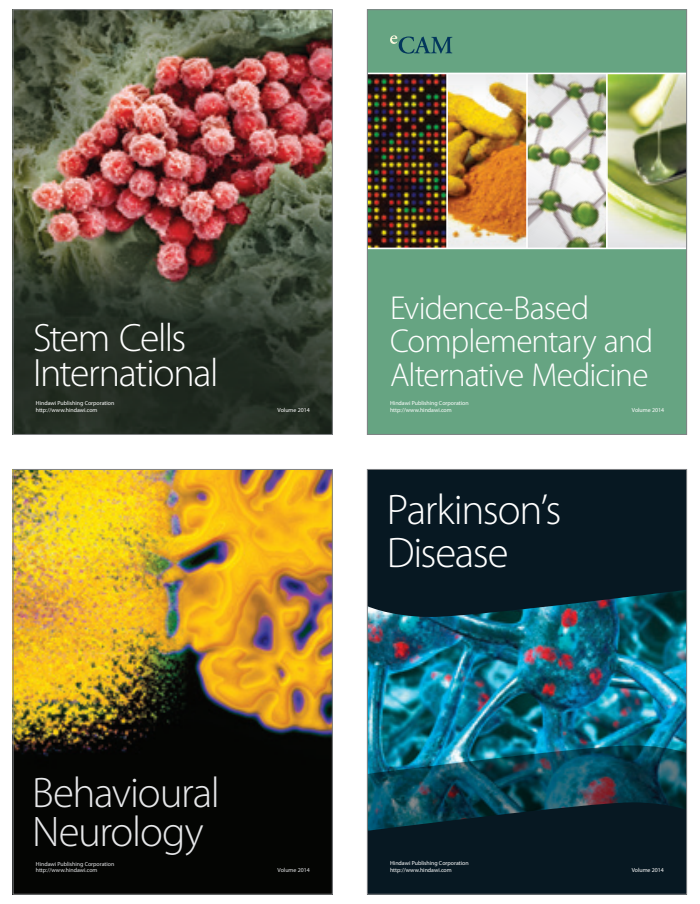
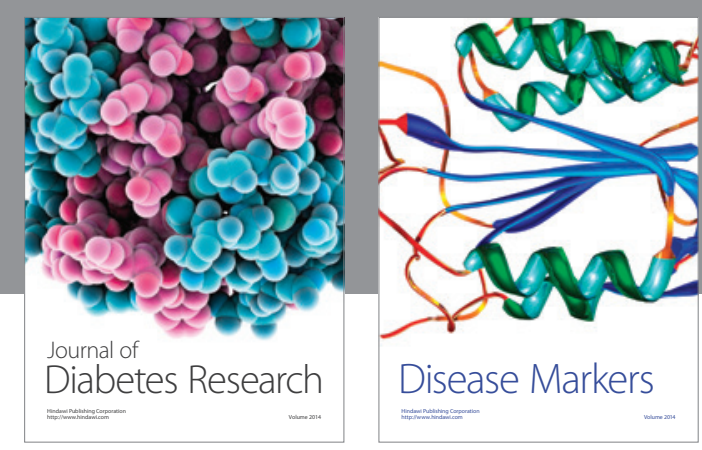

Disease Markers
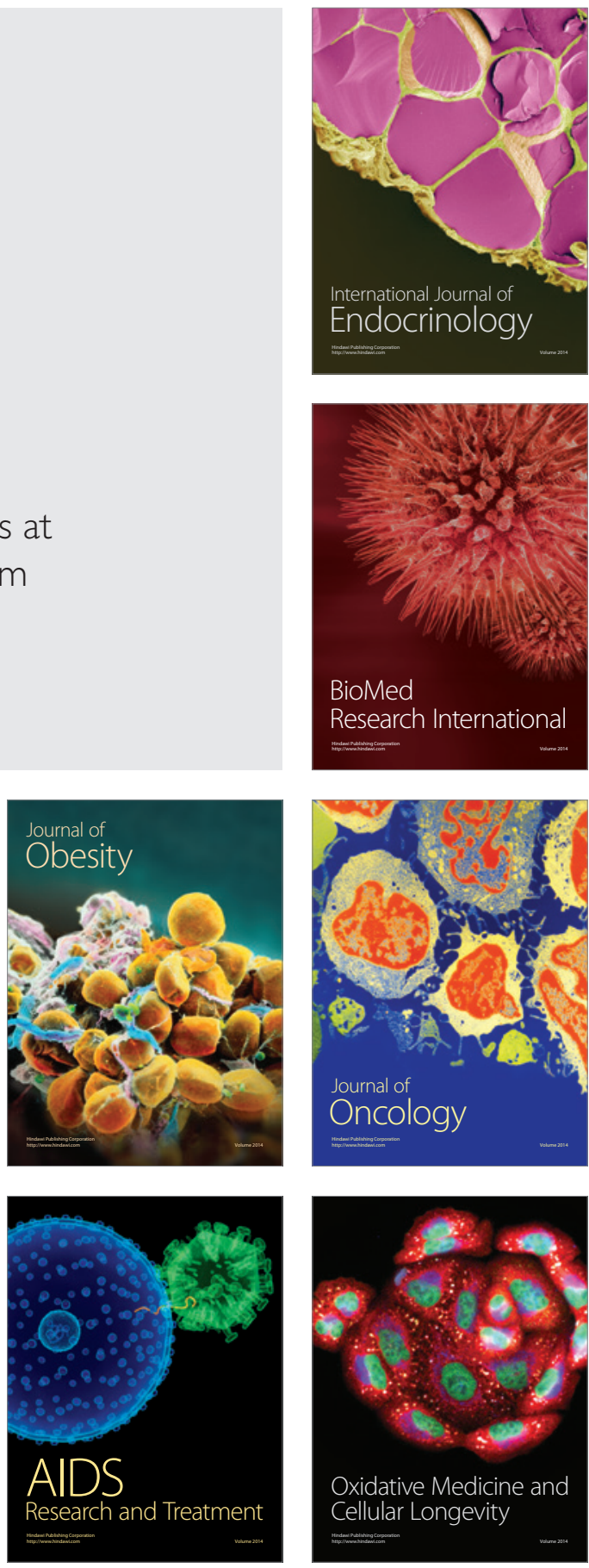